\title{
Развитие совета директоров как внутреннего механизма корпоративного управления
}

\author{
Ружанская Л.С. ${ }^{6}$
}

В работе представлена эволюичя практики применения совета директоров как внутреннего механизма корпоративного управления на российских предприятиях на основании анализа состава, структуры и функций советов. Практика работы советов на российских предприятиях демонстрирует рост спроса на эффективно работающие советьл в условиях концентрированной внешней собственности. Информаџионную базу исследования составили данные обследования 100 уральских открытых акционерных обществ. ${ }^{7}$ В работе выявлена агентская природа советов и специфика функиионирования совета в компаниях $c$ государственной собственностью.

\section{Постановка проблемы}

Приоритетность мотивации инвесторов в вопросе развития стандартов корпоративного управления невозможно переоценить. Несовершенство институциональной среды в России обусловило рост потерь от агентской проблемы в условиях разделения собственности и управления. Поэтому до настоящего времени типичные российские компании развивались в направлении роста концентрации собственности и объединения владения и менеджмента [Радыгин, Энтов, 2001]. Подобная модель корпоративного управления привела к преимущественному спросу на внутренние механизмы корпоративного управления. Отсутствие у стратегических инвесторов заинтересованности в инвестиционной активности компаний привело к тому, что внедрение стандартов корпоративного управления носило скорее демонстративный характер. При этом даже привлечение источников внешнего финансирования посредством демонстрации примеров лучшей практики корпоративного управления также не имело решающего значения для работы компаний [Яковлев, 2003].

Смена ориентиров инвесторов после 2000 г. с вывода активов из компаний к их развитию вызвала спрос на применение механизмов корпоративного управления в целях привлечения инвестиций в компании [Розинский, 2002; Яковлев и др., 2002]. Активизировались эмпирические исследования качества и спроса на стандарты корпоративного управления в России (Бюро экономического анализа, ГУ-ВШЭ, Институт экономики переходного периода, Центр экономических и финансовых исследований и разработок (ЦЭФИР), Российский экономический барометр (РЭБ)). Было обнаружено улучшение практики корпоративного управления и появление спроса компаний на отдельные нормы [Гуриев и др., 2003; Капелюшников, Демина, 2005; Развитие спроса, 2003; Структурные изменения, 2004; Dolgopyatova, Iwasaki, 2006]. Особое внимание в этом ряду обращает на себя совет директоров, как механизм защиты интересов сторонних акционеров, являющийся сильным сигналом для рынка относительно качества различных сторон корпоративной практики в компании. Возникает вопрос о своевременности постановки исследовательской гипотезы о развитии советов в российских компаниях как инструмента решения агентской проблемы - контроля менеджеров со стороны акционеров. Ушел ли сегодня в прошлое «бутафорский характер» [Долгопятова, 2004] деятельности совета директоров?

\footnotetext{
${ }^{6}$ Уральский государственный университет, экономический факультет.

${ }^{7}$ Опрос проводился методом углубленного интервью СЕО/председателей или членов советјd директоров средних и крупных ОАО Свердловской, Тюменской и Челябинской областей при финансовой поддержке МОНФ в 2002 и 2006 гг.
} 


\section{Обзор эмпирических исследований}

Совету директоров, как объекту эмпирических исследования в отечественной литературе, повезло мало. Незначительное количество работ по советам директоров в предыдущее время во многом объясняется сложностью формализованной оценки его деятельности. Отдельные аспекты функционирования советов директоров рассматривались в работах Авдашевой [2007], Авдашевой, Долгопятовой, Пляйнес [2007], Долгопятовой [2001, 2004, 2007], Долгопятовой, Уваровой [2007], Кузнецова, Муравьева [2002], «Структурные изменения» [2004]. Следует отметить, что интерес исследователей и практиков к работе советов и возможностям его использования повышается.

Незначительные эмпирические исследования работы советов в российских компаниях до 2002 г. выявляли неэффективность использования совета как механизма корпоративного управления. Типичная картина работы совета продемонстрирована выборочным анкетированием 60 крупнейших ОАО, регистрирующих выпуски ценных бумаг в ФКЦБ России, проведенным в 2001 г. ФКЦБ России совместно с Институтом фондового рынка (ИФРУ) и проектом ТАСИС «Консультационные услуги по инвестициям на фондовом рынке» (ИНВАС) ${ }^{8}$

Производилась сравнительная оценка лучшей и российской практик корпоративного управления. В отношении структуры совета были получены следующие результаты. Только в одной компании на 2001 г. наличествовал постоянно действующий комитет по вопросам стратегического развития. В то же время 70\% респондентов констатировали приоритетную роль советов в стратегическом планировании на предприятиях. Соотношение исполнительных и внешних членов совета составляло 30:70, в соответствии с Законом РФ «Об акционерных обществах»; в то же время соотношение зависимых и независимых директоров составило 80/20, что значимо меньше барьера в $30 \%$ от численности внешних директоров. Среди функций советов наименьшее внимание уделялось управлению рисками, раскрытию информации и созданию оперативных механизмов контроля над менеджментом. Процедура оценки деятельности совета и исполнительного руководства присутствовала на момент опроса только в одной компании, и в семи такие процедуры разрабатывались. При этом большинство компаний $(81 \%$ опрошенных) оценивали сложившуюся у них систему корпоративного управления как «хорошую, но требующую улучшений». Общим выводом исследования стала констатация факта формального использования механизма совета даже в тех российских компаниях, которые активнее остальных привлекают внешнее финансирование.

Материалы углубленных интервью АО, собранные коллективом сотрудников ГУ ВШЭ, показали [Долгопятова, 2004], что деятельность совета - зачастую дань формальным нормам права, и формальный ее характер обычно коррелирует со сращиванием совета с исполнительным менеджментом и стабильностью его состава. Самая консервативная политика в отношении совета директоров сохранилась при «полном совмещении» функций менеджмента и совета.

Внимание исследователей к проблеме организации корпоративного контроля в российских АО посредством разделения собственности и управления не случайно. Слабость институциональной среды, и в первую очередь защиты прав собственности, привела к трансформации основных механизмов корпоративного управления, выдвинув на первый план концентрированную собственность, совмещенную со сращиванием владения и управления, которые гарантировали крупному собственнику реализацию его интересов.

Однако отмеченная в начале статьи тенденция к изменению условий хозяйствования, привела инвесторов к пониманию необходимости изменения как системы управления

\footnotetext{
${ }^{8}$ Детальные результаты исследования «Структура и организация деятельности советов директоров российских

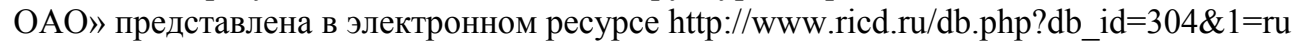


компаниями, так и системы корпоративных отношений. Это привело к значимым сдвигам в использовании механизмов корпоративного управления, в том числе совета директоров. Основными тенденциями развития института совета директоров в российских компаниях стали:

- уменьшение числа членов в советах, что свидетельствует о более эффективном использовании работы директоров [Структурные изменения, 2004];

- преобладание в типичных советах директоров независимых частных АО менеджмента компаний, что формализует характер работы советов [Долгопятова, 2001; Структурные изменения, 2004];

- повышение реального влияния совета на принятие стратегических решений на предприятиях [Структурные изменения, 2004];

- при разделении владения и управления, которое проявляется в том, что крупные собственники ${ }^{9}$ не являются одновременно топ-менеджерами компаний, а также в целом при высококонцентрированной внешней собственности появляются следующие черты работы советов: повышается доля представителей крупных внешних акционеров, в том числе государства; растет интенсивность обновления состава и в том числе его председателя, что усиливает агентскую природу совета [Долгопятова, 2007; Долгопятова, Уварова, 2007];

- особенности работы советов директоров в холдингах, как специфической форме организации бизнеса, предполагающей разделение собственности и управления, состоят в следующем: демонстрируется более активное использование инструментов корпоративного управления для построения внутри группы более прозрачных структур управления, и в том числе совета директоров (более низкая доля менеджеров в советах, более активное использование независимых директоров, более существенная роль совета при принятии решений, чем в независимых компаниях, более частая смена состава совета); наибольшее развитие совет директоров получил в тех группах, где дополнительными полномочиями регулятора и собственника обладает государство [Авдашева, 2007; Радыгин, 2004];

- специфика работы советов в АО с участием государства в собственности и участии представителей государства в советах директоров: у совета директоров шире функционал, в советы чаще входят независимые директора и представители мелких внешних собственников [Авдашева, Долгопятова, Пляйнес, 2007; Кузнецов, Муравьев, 2002]; в холдингах с участием государства совет директоров дает положительный эффект в мониторинге менеджмента, при этом наблюдается консолидация государственных пакетов в рамках холдингов [Авдашева, 2007].

Следует отметить, что большинство названных работ опирались на базы данных по российским АО без выделения регионов. Это давало возможность оперировать полномасштабными выборками, что повышало доказательность сделанных выводов. Кроме того, существует и техническая сложность, обусловившая малое количество «региональных» работ $^{10}$ : вопросы, связанные с отношениями собственности и корпоративного управления, раскрываются крайне нежелательно.

В то же время необходимость в подобных исследованиях настала. Это обуславливается в первую очередь той ролью, которую играют региональные органы власти ${ }^{11}$ как стейкхолдер и как собственник в региональных компаниях [Яковлев, 2003, 2005, 2007; Ясин и др., 2007]. Особенности модели корпоративного управления в каждом регионе обуславливаются взаимоотношениями с региональными властями: участие в управлении

\footnotetext{
9 Именно крупные собственники могут реально претендовать на высшие исполнительские посты, что гарантирует им защиту прав собственности.

10 За исключением, пожалуй, известной работы: Басаргин В., Перевалов Ю. Анализ закономерностей формирования корпоративного контроля на приватизированных предприятиях // Проблемы прогнозирования, 2000, № 5, с. 120-138.

11 Будем в последующем называть их «региональное государство», понимая под этим муниципальную и региональную собственность. Федеральное владение значимо, в первую очередь, для крупнейших компаний, которые имеют скорее не региональное, а федеральное значение.
} 
компаниями через инструменты корпоративного управления (совет директоров), посредством предоставления государственной помощи (финансовой и косвенной), а также посредством неформальных отношений с компаниями, через которые региональные власти с ограниченными бюджетными возможностями осуществляют свои регулирующие функции.

Данное исследование концентрирует внимание на особенностях работы компаний Уральского региона с сильным присутствием государства в собственности АО. Для выявления специфики государства как стейкхолдера необходимо проведение дополнительного исследования, выходящее за рамки данной работы.

\section{Эмпирическая база исследования}

Информационной базой исследования стали интервью с руководителями/председателями советов директоров $100 \mathrm{OAO}$ Уральского региона в начале 2006 г. $^{12}$ по вопросам корпоративного управления. Опрос проводился методом глубинного интервью, а также был дополнен анкетами для самозаполнения.

В общей численности зарегистрированных в Уральском федеральном округе предприятий открытые акционерные общества, попавшие в выборку, занимают 0,3\%, в то время как оборот компаний составляет треть промышленной продукции Урала $(32,76 \%)$, что свидетельствует о попадании в выборку сверхкрупных компаний. Доля занятых на предприятиях выборки в среднесписочной численности персонала промышленности составляет 9,35\% по Уральскому федеральному округу и $1,09 \%$ по России. Средний показатель, рассчитанный на основе данных о среднесписочной численности работников, составил 2957 человек. Численность работников по выборке колеблется от 106 человек (ОАО Камышловский завод «Лесхозмаш») до 30653 человек (ОАО Нижнетагильский металлургический комбинат НТМК). ${ }^{13}$ Описание предприятий выборки в размерном разрезе приведено в приложении, таблицы 1 и 2.

Отраслевая структура выборки соответствует распределению отраслей в Уральском регионе, где превалируют машиностроение, черная и цветная металлургия, а также развиты инфраструктура, оборонный комплекс и НИОКР. Смещение выборки в сторону черной и цветной металургии связано с тем, что большинство предприятий данной отрасли являются открытыми акционерными обществами. Уральский экономический регион развивался как единый территориально-производственный комплекс, поэтому сложилась глубокая специализация отдельных его областей. Так, отраслевой структуре Челябинской и Свердловской областей присуща специализация на выпуске продукции металлургии и машиностроения. Подробнее отраслевая структура выборки в сравнении с генеральной совокупностью представлена в таблице 3 приложений.

Итоговое совместное распределение выборочной совокупности по двум параметрам создания - отраслям и размеру - показывает, что открытые акционерные общества чаще встречаются в базовых отраслях промышленности, для них характерны интеграционные процессы, большая численность занятых и сложные имущественные отношения в группе.

\footnotetext{
${ }^{12}$ Исследования были осуществлены при финансовой поддержке Московского общественного научного фонда в 2006 г., а также была получена финансовая поддержка на обработку данных от Московского научного фонда экономических исследований академика Н.П. Федоренко (2006 г.) и НСF (2007 г.).

${ }^{13}$ Более подробно описание выборки и основных результатов опроса приведено в работе Ружанской, Крутикова «Эволюция корпоративного поведения уральских корпораций: первые итоги исследовательского проекта. Инструменты анализа и управления переходными состояниями в экономике». Екатеринбург, 2006, с. 94-113. 


\section{Особенности работы совета директоров в уральских компаниях}

\section{1. Общие характеристики работы советов директоров в уральских АO}

Обследование показало, что обычной практикой уральских компаний является ситуация, когда в совет директоров предприятия входит 7 человек, причем с ростом размера предприятия растет и совет (от 3 человек до 15 максимально). На большинстве предприятий состав совета директоров за 2003-2005 гг. активно менялся, причем только за 2005 г. смена состава происходила на 44 из 100 опрошенных компаний. Происходившие изменения были связаны как с экономическими (изменения структуры собственности, интеграционные процессы), так и неэкономическими причинами (возраст, состояние здоровья, ротация акционерами своих представителей без изменения состава акционеров; смена представителей государства в силу политических изменений). Нестабильность состава совета директоров в большинстве случаев была связана с решением акционеров, что подчеркивает агентскую природу совета и интерес со стороны акционеров к этому механизму корпоративного управления. В то же время респонденты подчеркивали, что акционеры не всегда воспринимают совет только как механизм мониторинга за менеджментом, но и как дополнительный инструмент управления компанией. Наиболее ярко это проявляется в управляющих компаниях бизнес-групп, где совет помимо прочего играет еще и координирующую роль.

Независимые директора присутствовали на начало 2006 г. в 20\% опрошенных ОАО. Наличие независимых директоров определяется во многом структурой собственности: наиболее часто независимые директора представляют интересы аутсайдеров - иностранных инвесторов, государства и институциональных инвесторов. Внешние собственники активно мотивированы на использование инструментов корпоративного управления в реалиазции своего контроля за компанией.

Наиболее распространенным режимом работы совета директоров являются ежеквартальные заседания. Эта практика распространена в целом по России. В то же время на $27 \%$ ответивших предприятий заседания происходят раз в месяц и чаще. Однако число заседаний не отражает качества работы компаний.

Таблица 1. Частота заседаний совета директоров по всей выборке предприятий

\begin{tabular}{|l|l|l|}
\hline \multicolumn{1}{|c|}{ Частота заседаний СД } & \multicolumn{1}{c|}{ Количество } & \% отв. \\
\hline Один раз в год & 5,00 & $5,15 \%$ \\
\hline Один раз в полугодие & 19,00 & $19,59 \%$ \\
\hline Один раз в квартал & 44,00 & $45,36 \%$ \\
\hline Один раз в месяц & 17,00 & $17,53 \%$ \\
\hline Чаще & 10,00 & $10,31 \%$ \\
\hline По необходимости & 2,00 & $2,06 \%$ \\
\hline ИТОГО & 97 & $100 \%$ \\
\hline
\end{tabular}

За период с 2002-го по 2006 г. расширилась практика создания комитетов в совете директоров. Такая институционализация функций совета говорит, во-первых, о фактическом использовании совета как органа управления АО; во-вторых, о повышении специализации принятия решений, хотя не следует забывать и о третьей причине распространения комитетов - формальное следование стандартам корпоративного поведения. Наибольшее распространение получили комитет по аудиту (36\% респондентов) и комитет по 
стратегическому управлению и финансам (26\%). Первое определено существующей тенденцией в дополнение функций внешнего аудитора членами комитета по аудиту, второе же отражает сущность деятельности совета директоров как контрольно-наблюдательного органа.

\section{Таблица 2. Статус председателя совета директоров}

\begin{tabular}{|l|l|l|}
\hline \multicolumn{1}{|c|}{ Статус председателя СД } & Количество АО & \multicolumn{1}{|c|}{ \% отв. } \\
\hline Генеральный директор ОАО & 22 & $22,22 \%$ \\
\hline Топ-менеджер бизнес-группы & 23 & $23,23 \%$ \\
\hline Представитель государства & 26 & $26,26 \%$ \\
\hline Независимый директор & 27 & $27,27 \%$ \\
\hline ИТОГО & 98 & $100 \%$ \\
\hline \hline
\end{tabular}

Председатель совета директоров в большинстве случаев так или иначе связан с предприятием: представитель головной организации, бывший руководитель предприятия. Советы директоров на стратегически важных и крупных предприятиях возглавляются представителями органов государственной власти ${ }^{14}$.

Можно выделить общие для многих советов сферы компетенции: формулировка стратегии развития компании, согласование финансовых вопросов, утверждение отчетности перед основной массой акционеров. Необходимо отметить, что сфера компетенции совета директоров не распространяется на кадровые вопросы. В то же время сфера компетенции совета директоров различается от предприятия к предприятию, что обусловлено в первую очередь принадлежностью компаний к интегрированным структурам. Здесь на советы ложатся дополнительные функции по принятию решений структурного характера и согласованию интересов холдинга и его рядовых членов.

Таблица 3. Структура совета дирекоров по выборке предприятий 2006 г. ${ }^{15}$

\begin{tabular}{|l|l|}
\hline Структура совета директоров по всей выборке & \% отв. \\
\hline 1..Высший руководитель предприятия & 33,33 \\
\hline 2. Заместители высшего руководителя предприятия & 24,29 \\
\hline 3. Представители государства & 10,48 \\
\hline 4. Иностранные граждане & 1,43 \\
\hline 5. Представители банков и институт. инвесторов & 6,19 \\
\hline 6. Представители иностранных инвесторов & 0,95 \\
\hline 7. Другие & 22,86 \\
\hline 8. Сторонние акционеры, российские граждане & 0,48 \\
\hline ИТОГО & 100,00 \\
\hline
\end{tabular}

14 Как правило, это непосредственно руководители департаментов региональных администрации по управлению государственным имуществом в ранге заместителя губернатора, либо лица, непосредственно стоящие за ними в административной иерархии.

${ }^{15}$ Всего на этот вопрос ответило 98 компаний. 


\section{Рисунок 1}

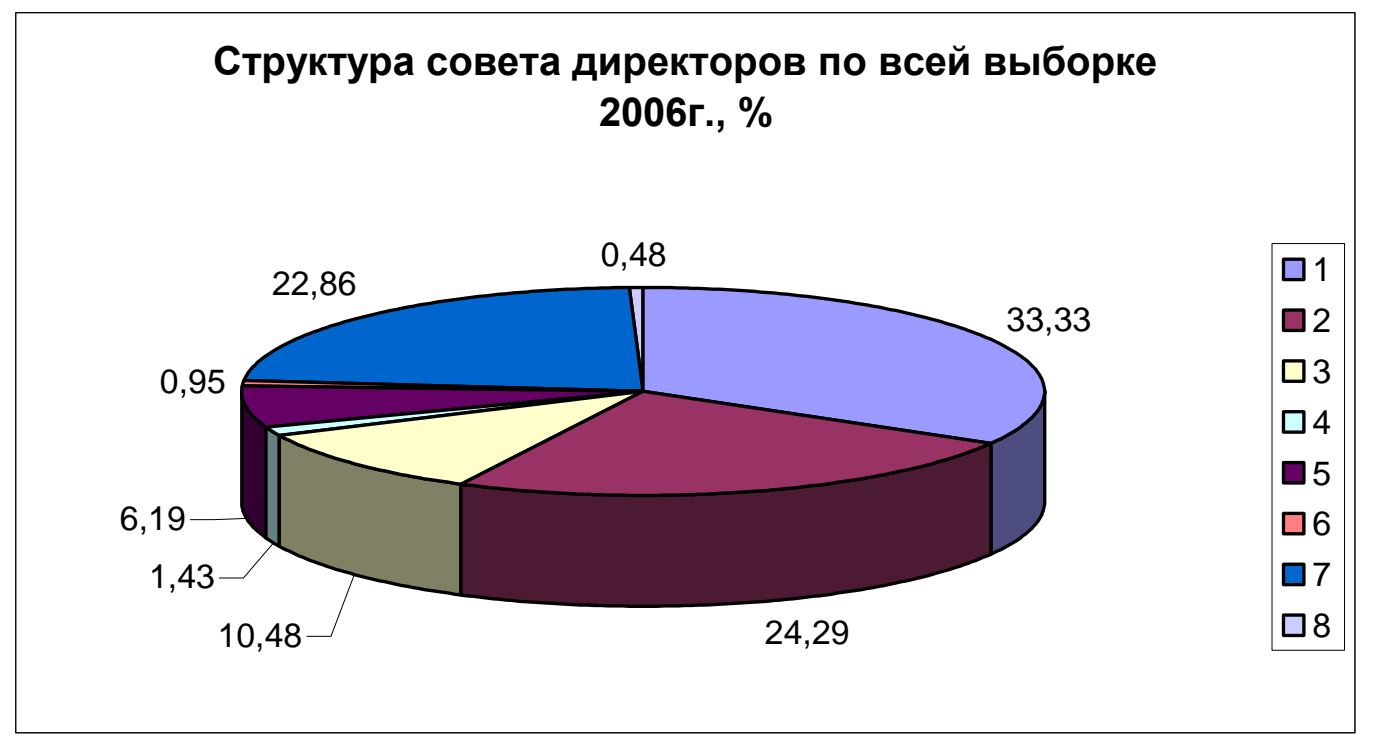

С точки зрения представительства интересов контролирующих групп в совете директоров наиболее часто наравне с государством представлены акционеры-инсайдеры ${ }^{16}$ : представители трудового коллектива, топ-менеджеры; в то время как с точки зрения модели корпоративного контроля доминирует контроль внешних собственников. Только государство, значимо представленное в структуре собственности уральских компаний, сохраняет свои позиции и по представительности в совете директоров. Причем доля менеджеров в составе совета растет с падением уровня концентрации собственности. Представительство менеджмента в совете ниже в управляющих компаниях холдингов и выше для рядовых членов и независимых предприятий. В управляющих компаниях наблюдается самая высокая доля государственных представителей. Факт несовпадения модели корпоративного контроля и модели совета директоров может свидетельствовать, с одной стороны, о том, что происходит объединение интересов внешних собственников с менеджментом через систему представительства в совете директоров; с другой стороны, это может свидетельствовать и о том, что крупные внешние собственники приводят с собой команду наемных менеджеров, которые участвуют в работе совета директоров для исключения вмешательства иных категорий акционеров.

Использование совета как инструмента корпоративного контроля со стороны доминирующих собственников (распространение контрольных и блокирующих пакетов, а также их средние размеры на уральских АО превышают среднероссийские) подчеркивает тот факт, что многие респонденты отмечали подчиненный характер функционирования совета директоров. Другой, неформальный, аспект деятельности этого института заключается в системе согласований позиций по важным вопросам, которые происходят между всеми «группами влияния». В то же время компании, входящие в интегрированные структуры, называли совет директоров органом, который способствует согласованию интересов внутри группы и усиливает управляемость холдинговых структур.

\footnotetext{
16 Этот вывод согласуется с показателем 80\%-ного присутствия в советах инсайдеров, полученного в ходе обследования 822 крупных и средних акционерных обществ промышленности и связи, проведенного в 2005 г. (Долгопятова Т.Г. Эмпирический анализ корпоративного контроля в российских компаниях: когда крупные акционеры отходят от исполнительного управления? Mimeo, 2007)
} 


\section{2. Совет директоров и концентрация собственности}

Структура собственности уральских компаний от момента акционирования до 2006 года имела в целом те же характеристики, что и общероссийская картина: место инсайдеров - администрации и трудового коллектива, занимают постепенно внешние акционеры; концентрированная собственность сохраняется как наиболее существенный механизм мониторинга. На момент акционировании у трети предприятий выборки присутствовал собственник с контрольным пакетом акций $(34 \mathrm{AO})^{17}$, к 2006 г. этот показатель не изменился, однако произошли сдвиги внутри категорий собственников: сократилось количество контрольных пакетов в руках государства (с 16 до 8 AO) и работников предприятия, в то время как вырос контроль со стороны внешних собственников: юридических лиц, сторонних физических лиц и иностранных инвесторов. Средний размер контрольного пакета по всем типам собственников в 2002 г. доходил до 63\%, в 2006 г. он составил 59,8\%. выборки

Таблица 4. Наличие контрольного пакета $(50 \%+1$ акция) на предприятиях

\begin{tabular}{|l|l|l|}
\hline $\begin{array}{l}\text { Тип владельца контрольного } \\
\text { пакета (всего 34 ОАО) }\end{array}$ & $\begin{array}{l}\text { Доля компаний } \\
\text { момент } \\
\text { акционирования, \% }\end{array}$ & $\begin{array}{l}\text { Доля компаний } \\
\text { в 2006 г., \% }\end{array}$ \\
\hline Государство & 47 & 24 \\
\hline $\begin{array}{l}\text { Работники предприятия; } \\
\text { в т.ч.: }\end{array}$ & 18 & 15 \\
\hline генеральный директор & 3 & 9 \\
\hline Сторонние физические лица & 15 & 21 \\
\hline $\begin{array}{l}\text { Юридические лица } \\
\text { нефинансовые организации }\end{array}$ & 18 & 21 \\
\hline $\begin{array}{l}\text { Банки и прочие финансовые } \\
\text { организации }\end{array}$ & 0 & 6 \\
\hline Иностранные инвесторы & 0 & 6 \\
\hline ИТОГО & 100 & 100 \\
\hline
\end{tabular}

Ситуация формального контроля по признаку наличия контрольного пакета акций в руках собственника несколько отличается от ситуации «реального доминирования» собственника, под которой понимается возможность реально влиять на принятии решений в компании. Своим преимуществом во владении акциями пользуются в первую очередь самые мотивированные на управление инвесторы - сторонние юридические лица нефинансового характера, являющиеся стратегическими инвесторами, и сторонние физические лица (таблица 5).

\footnotetext{
${ }^{17}$ В расчет не принимались компании, от которых не был получен ответ, либо не был назван тип собственника, владеющего контрольным пакетом. 
Таблица 5. Наличие доминирующего собственника на предприятиях выборки в 2006 г. $^{18}$

\begin{tabular}{|c|c|c|}
\hline $\begin{array}{l}\text { Тип доминирующего собственника } \\
\text { (всего 51 ОАО) }\end{array}$ & $\begin{array}{l}\text { На момент } \\
\text { Акционирования, \% }\end{array}$ & 2006 г., \% \\
\hline Государство & 31 & 15 \\
\hline Работники предприятия; в т.ч. & 20 & 10 \\
\hline генеральный директор & 2 & 8 \\
\hline Сторонние физические лица & 20 & 25 \\
\hline $\begin{array}{l}\text { Юридические лица }- \text { нефинансовые } \\
\text { организации }\end{array}$ & 12 & 22 \\
\hline Банки и прочие финансовые организации & 2 & 7 \\
\hline Иностранные инвесторы & 0 & 3 \\
\hline Нет реального доминирования & 4 & 2 \\
\hline Прочие & 10 & 7 \\
\hline ИТОГО & 100 & 100 \\
\hline
\end{tabular}

Высокая концентрация собственности накладывает отпечаток на использование инструментов корпоративного управления, и в том числе на совет директоров. С точки зрения агентской теории, советы в АО с концентрированной собственностью должны включать большую долю представителей крупных собственников.

Таблица 6. Структура совета дирекоров в АО с высокой концентрацией собственности $(50 \%+1 \text { акция })^{19}$

\begin{tabular}{|l|l|}
\hline Тип представителя & \% отв. \\
\hline 1. Высший руководитель предприятия & 30,51 \\
\hline 2. Заместители высшего руководителя предприятия & 23,73 \\
\hline 3. Представители государства & 13,56 \\
\hline 4. Иностранные граждане & 3,39 \\
\hline 5. Представители банков и институт. инвесторов & 1,69 \\
\hline 6. Представители иностранных инвесторов & 0,00 \\
\hline 7. Другие & 25,42 \\
\hline 8. Собственники-владельцы & 1,69 \\
\hline ИТОГО & 100,00 \\
\hline
\end{tabular}

\footnotetext{
${ }^{18}$ Самооценка предприятий.

${ }^{19}$ Всего на этот вопрос ответило 30 компаний из 65, представивших полную структуру собственности.
} 


\section{Рисунок 2}

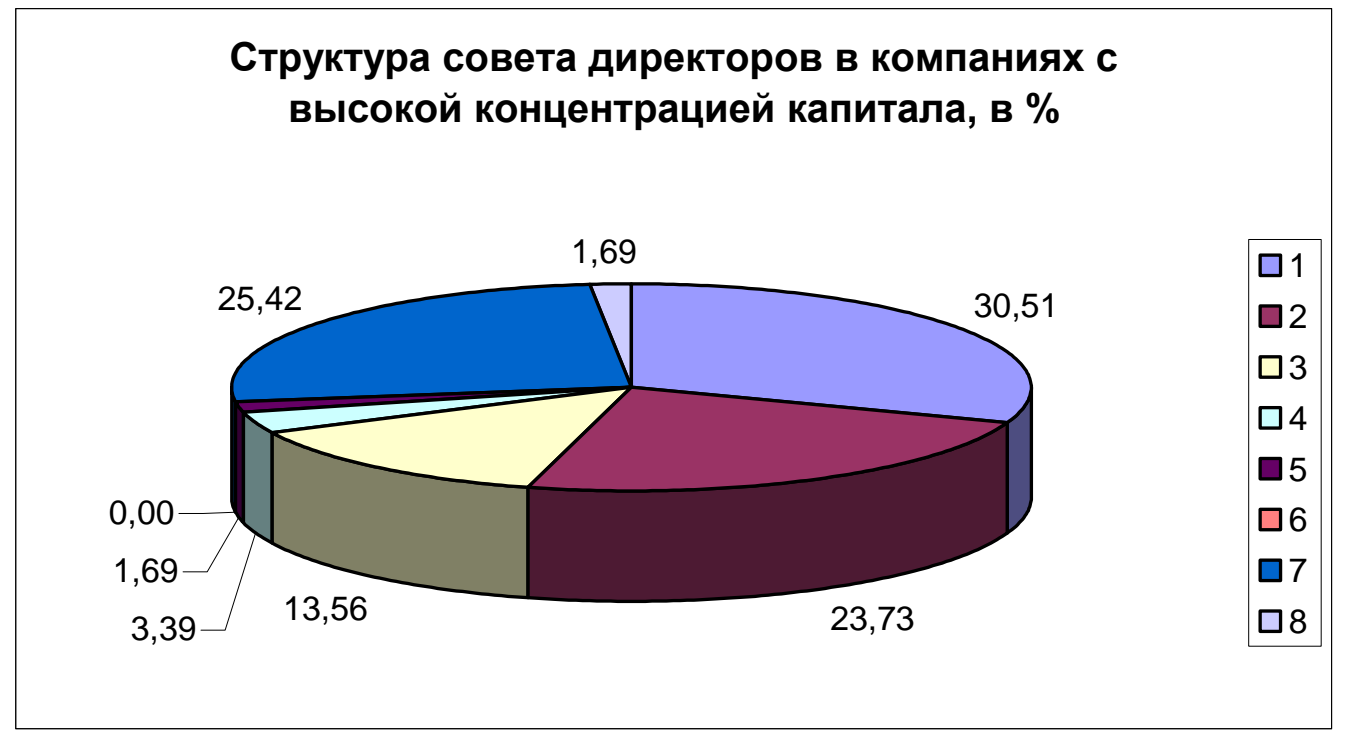

В уральских АО с высококонцентрированной собственностью основную долю членов советов составляют менеджеры предприятий - высший руководитель либо его заместители. Это в целом характерно для многих российских компаний [Долгопятова, 2007]. Менеджмент компаний захватывает советы, подчиняя себе контрольный орган. В то же время в структуре совета слишком большую долю занимает группа «другие», что свидетельствует о непрозрачности структуры собственности. Очень низка доля институциональных инвесторов: крупные собственники не пускают представителей миноритариев к рычагам управления компаниями. Ограничить представительство государства крупные собственники не могут из-за законодательных требований, а также по причине легкого вступления в альянс с госпредставителями, как отмечали сами респонденты. Концентрированная собственность демонстрирует сращивание владения и управления: крупные владельцы участвуют не только в управлении, но и в работе совета директоров.

В отличие от концентрированной собственности, в компаниях со средней концентрацией (у крупнейшего собственника находится пакет акций размером от 25 до $50 \%$ ), доля менеджеров еще выше, но ниже доля государства как наиболее представленного внешнего инвестора в случае с концентрированной собственностью.

Таблица 7. Структура совета дирекоров в АО со средней концентрацией собственности (25-50\% акций у крупнейшего собственника)

\begin{tabular}{|l|l|}
\hline Тип представителя & \% отв. \\
\hline 1. Высший руководитель предприятия & 35,56 \\
\hline 2.з Заместители высшего руководителя предприятия & 17,78 \\
\hline 3. Представители государства & 8,89 \\
\hline 4. Иностранные граждане & 0,00 \\
\hline 5. Представители банков и институт. инвесторов & 11,11 \\
\hline 6. Представители иностранных инвесторов & 0,00 \\
\hline 7. Другие & 26,67 \\
\hline 8. Сторонние акционеры, российские граждане & 0,00 \\
\hline ИТОГО & 100,00 \\
\hline
\end{tabular}

\footnotetext{
${ }^{20}$ Всего на этот вопрос ответило 20 компаний из 65 , представивших полную структуру собственности. Выпуск \#4, 2007 


\section{Рисунок 2}

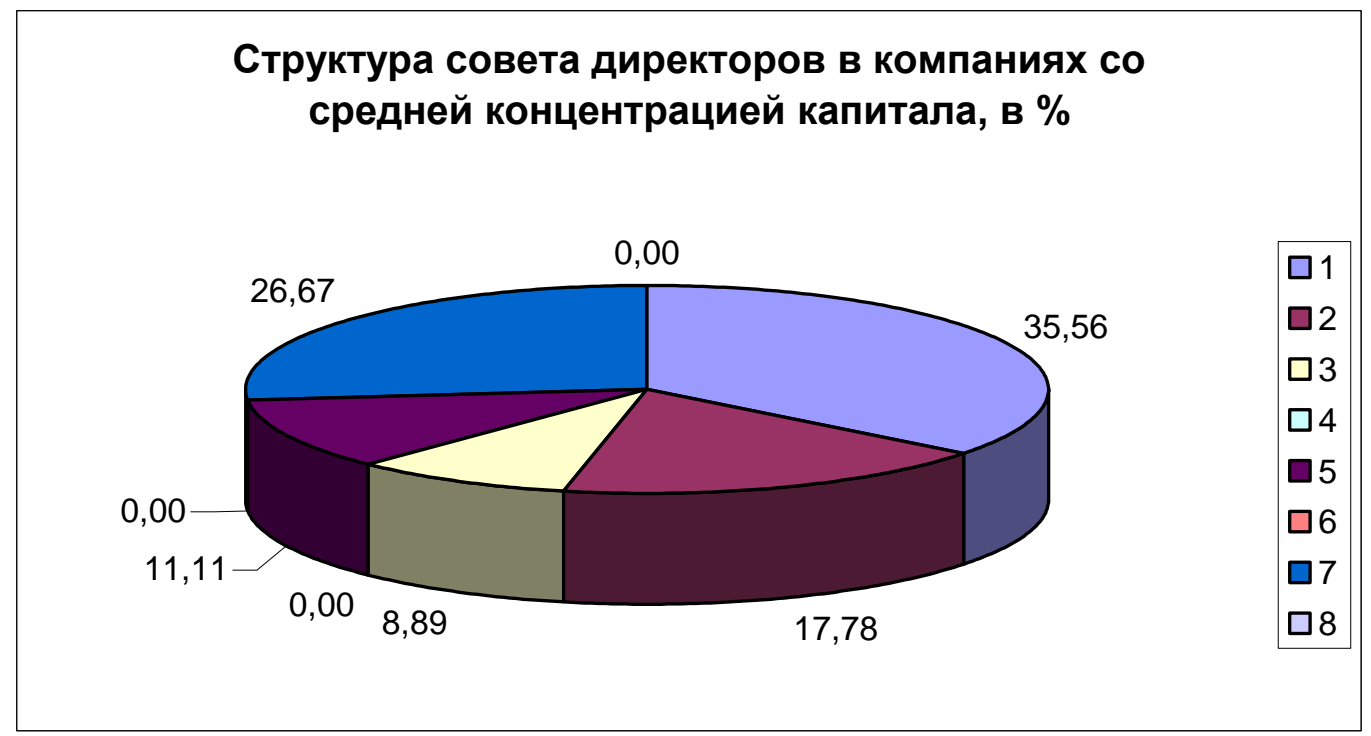

Высокая значимость советов для представителей банков и институциональных инвесторов свидетельствует об их большей роли в мониторинге за менеджментом компании, хотя и эта группа компаний также отличается закрытостью информации о собственности, судя по доле «других членов» совета.

Таблица 8. Структура совета дирекоров в АО со средней концентрацией собственности (менее $25 \%$ акций у крупнейшего собственника) ${ }^{21}$

\begin{tabular}{|l|l|}
\hline Тип представителя & \% отв. \\
\hline 1. Высший руководитель предприятия & 42,86 \\
\hline 2. Заместители высшего руководителя предприятия & 25,00 \\
\hline 3. Представители государства & 3,57 \\
\hline 4. Иностранные граждане & 3,57 \\
\hline 5. Представители банков и институт. инвесторов & 3,57 \\
\hline 6.представители иностранных инвесторов & 0,00 \\
\hline 7. Другие & 21,43 \\
\hline 8. Сторонние акционеры, российские граждане & 0,00 \\
\hline ИТОГО & 100,00 \\
\hline
\end{tabular}

\footnotetext{
${ }^{21}$ Всего на этот вопрос ответило 15 компаний из 65 , представивших полную структуру собственности. Выпуск \#4, 2007

(C) Электронный журнал Корпоративные Финансы, 2007
} 
Рисунок 3

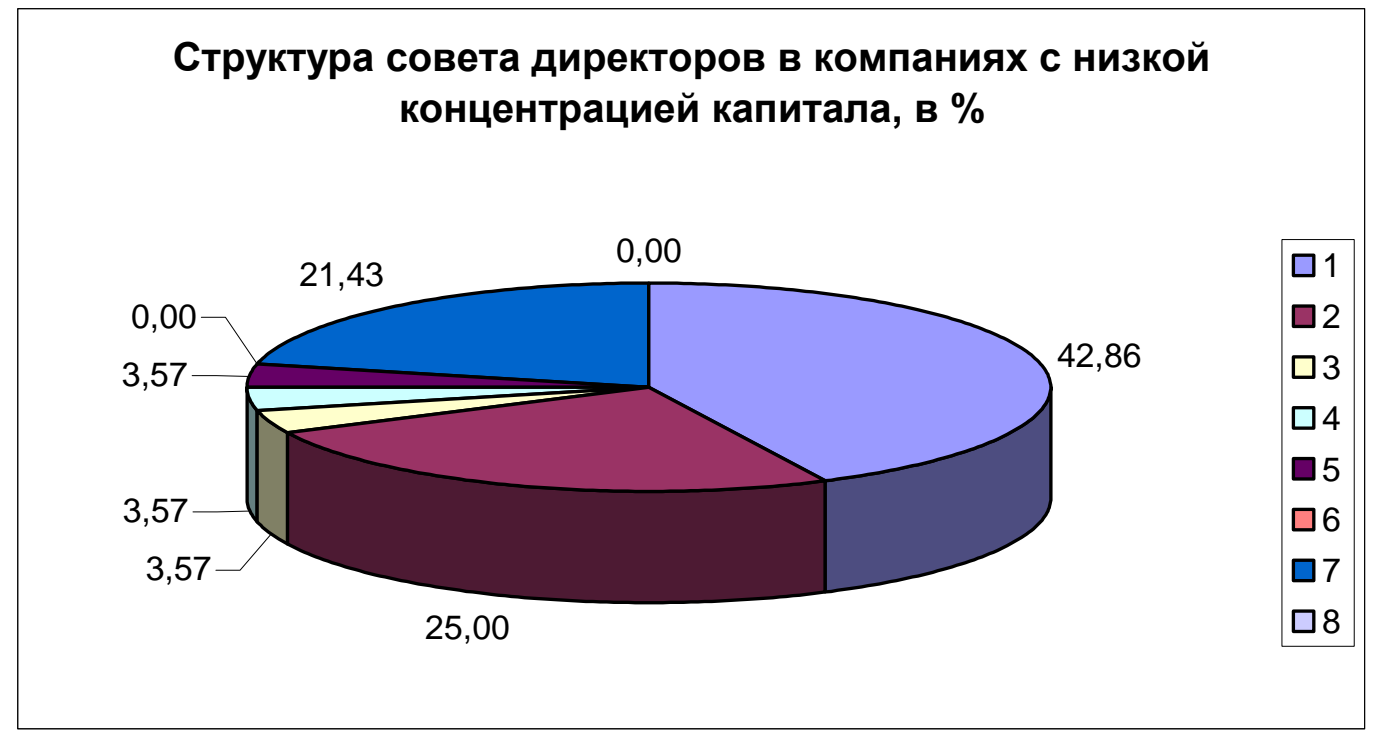

При низкой концентрации капитала доля менеджмента в совете наиболее высока, никто из прочих инвесторов не может противостоять управленцам по силе. Все основные группы сторонних инвесторов, включая государства, представлены в равной степени, за исключением иностранных инвесторов, которые не присутствуют в совете. Причем все число представителей аутсайдров, вместе взятых, несопоставимо мало по сравнению с долей менеджеров.

Таблица 9. Обновление состава совета директоров в 2003-2006 гг., \% ответивших

\begin{tabular}{|l|l|l|l|l|}
\hline \multirow{2}{*}{$\begin{array}{l}\text { Состав совета } \\
\text { директоров }\end{array}$} & По всей & \multicolumn{4}{|l|}{ Группы АО с концентрацией капитала } \\
\cline { 3 - 6 } & выборке & Низкая & Средняя & Высокая \\
\hline Сохранился & 50.45 & 52,83 & 48,39 & 48,28 \\
\hline Сменился & 49.55 & 47,16 & 51.72 & 51,61 \\
\hline Всего АО & 65 & 15 & 20 & 30 \\
\hline
\end{tabular}

Обновление состава совета является еще одной характеристикой его агентской природы. В компаниях с высококонцентрированной собственностью состав совета наименее стабилен, хотя отличия по группам концентрации незначительны. Нестабильность совета по воле крупных акционеров является свидетельством возможности акционеров влиять на работу компании. Об этом же говорит и высокая степень обновления топ-менеджеров компаний (таблица 10).

Таблица 10. Обновление топ-менеджера в 2003-2005 гг., \% ответивших

\begin{tabular}{|l|l|l|l|l|}
\hline \multirow{2}{*}{$\begin{array}{l}\text { Состав совета } \\
\text { директоров }\end{array}$} & По всей & \multicolumn{4}{|l|}{ Группы АО с концентрацией капитала } \\
\cline { 3 - 5 } & выборке & Низкая & Средняя & Высокая \\
\hline Сохранился & $45,00 \%$ & $44,83 \%$ & $39,21 \%$ & $21,63 \%$ \\
\hline Сменился & $55,00 \%$ & $55,17 \%$ & $60,79 \%$ & $78,37 \%$ \\
\hline Всего АО & 65 & 15 & 20 & 30 \\
\hline
\end{tabular}


Таким образом, можно заключить, что во всех случаях в советах доминируют представители менеджмента, что снижает значение совета директоров как механизма мониторинга за менеджментом. В то же время можно сказать, что крупные инвесторы монополизируют власть в компаниях как посредством представительства в менеджменте, так и в совете. Меньшая концентрация собственности позволяет миноритарным инвесторам усилить свое влияние через совет директоров. В то же время крупные инвесторы демонстрируют свое влияние на менеджмент посредством использования угрозы увольнения как членов совета, так и топ-менеджеров компаний.

\section{3. Совет директоров и участие в собственности государства как собственника уральских компаний}

В целом государственное участие в собственности и управлении региональными компаниями проявляется в практике работы совета. На предприятиях, где государство является собственником, советы имеют наиболее развитую структуру; смена председателя совета используется чаще обычного. Участие государства в управлении без участия в собственности институционализируется в участии представителя региональной власти в работе совета. Ограниченность бюджетных возможностей региональных компаний и регионального правительства в условиях жесткой конкуренции приводит к росту спроса на административную поддержку. Если ввести в анализ влияние государства на качество корпоративного управления, то на уровне региона государство выступает инициатором импорта норм корпоративного управления.

Агентская проблема может решаться не только с помощью стандартных механизмов корпоративного управления, то есть корпоративного управления в узком смысле, но и с помощью вспомогательных инструментов, таких как наличие дополнительных механизмов мониторинга в руках собственника. Такими инструментами в первую очередь обладает государство как собственник, которое, с одной стороны, выступает регулятором, а с другой, открывает доступ к ресурсам, повышающим конкурентоспособность компании. Это накладывает отпечаток на использование традиционных инструментов мониторинга в компаниях с государственным участием.

Кроме того, отмечающийся в последнее время спрос на организационную государственную поддержку выдвигает на первое место совет директоров как форму организации участия государства в управлении частными компаниями.

Государство является типичным представителем акционеров, обладающих контролем над уральскими корпорациями. Средний размер контрольного пакета, принадлежащий ему, колеблется в течение всего наблюдаемого периода вокруг 60\%. Объяснением этому может служить концентрированное расположение на Урале предприятий, так или иначе связанных с ВПК либо имеющих стратегическое значение. Средний размер пакета у государства снизился незначительно — с 38,4 до 33,5\%, при этом с 2004-го по 2005 г. средний пакет даже увеличился. В то же время распространение акционерной собственности на АО Урала заметно сократилось: с момента акционирования 16,3\% выборки лишились государства в составе собственников, в основном за счет мелких АО. 
Таблица 11. Участие государства в собственности компаний

\begin{tabular}{|l|l|l|l|l|}
\hline Показатель & $\begin{array}{l}\text { На момент } \\
\text { акционирования }\end{array}$ & 2002 г. & 2004 г. & 2005 г. \\
\hline $\begin{array}{l}\text { Доля предприятий с } \\
\text { участием } \\
\text { собственности } \\
\text { государстве в общем } \\
\text { числе респондентов }\end{array}$ & $46,4 \%$ & $46,0 \%$ & $32,4 \%$ & $30,1 \%$ \\
\hline $\begin{array}{l}\text { Средний размер } \\
\text { пакета государства }\end{array}$ & $38,94 \%$ & $38,5 \%$ & $32,7 \%$ & $33,5 \%$ \\
\hline $\begin{array}{l}\text { Средний размер } \\
\text { контрольного пакета, } \\
\text { принадлежащего } \\
\text { государству }\end{array}$ & $58,6 \%$ & $69,6 \%$ & $60,9 \%$ & $59,5 \%$ \\
\hline
\end{tabular}

Поскольку в обследовании 2006 г. компании не выделяли уровни государства, данные о динамике участия федеральной, региональной и муниципальной власти приводятся только для $2002 \Gamma^{22}$.

Таблица 12. Участие государства разных уровней в собственности уральских компаний

\begin{tabular}{|c|c|c|c|c|}
\hline \multirow[b]{2}{*}{ Уровень власти } & \multicolumn{2}{|l|}{2002 г. } & \multicolumn{2}{|c|}{ На момент акционирования } \\
\hline & $\begin{array}{l}\text { Доля } \\
\text { ответивших }\end{array}$ & $\begin{array}{l}\text { Средний пакет } \\
\text { обыкновенных } \\
\text { акций }\end{array}$ & $\begin{array}{l}\text { Доля } \\
\text { ответивших }\end{array}$ & $\begin{array}{l}\text { Средний пакет } \\
\text { обыкновенных } \\
\text { акций }\end{array}$ \\
\hline Федеральный уровень & $58,82 \%$ & $44,43 \%$ & $47,37 \%$ & $46,21 \%$ \\
\hline Региональный уровень & $23,53 \%$ & $27,25 \%$ & $36,84 \%$ & $28,28 \%$ \\
\hline Муниципальный уровень & $11,76 \%$ & $13,00 \%$ & $15,79 \%$ & $32,67 \%$ \\
\hline
\end{tabular}

За анализируемый период на фоне общего сокращения доли государства в собственности произошли изменения внутри неоднородного собственника - государства: сократилось участие в собственности региональных и муниципальных властей и увеличилось участие федеральных, в то время как пакеты каждого уровня сократились. При этом наибольшее сокращение коснулось муниципального государства. Это в первую очередь связано с приватизацией пакетов, принадлежащих муниципальным властям, как наименее значимым для государства в социальном и общеэкономическом плане. Кроме того, муниципальное правительство не имеет значимых финансовых ресурсов для поддержания своего имущества в виде финансирования компаний.

В отношении представления государственной собственности в разрезе концентрации капитала выделяются следующие тенденции (см. Приложения, таблица 4.1, 4.2). Как доминирующий собственник, обладающий контрольным пакетом, государство сдает свои позиции по сравнению с моментом акционирования компаний за счет сокращения числа закрепленных пакетов. Место государства занимают сторонние юридические и физические лица, причем среди юридических лиц значимое место принадлежит бизнес-группам,

\footnotetext{
${ }^{22}$ В данной работе не приводятся полные результаты первого раунда опроса уральских компаний, проведенного при финансовой поддержке МОНФ в 2002 году, поскольку круг вопросов был значительно уже. 
распространенным в металлургии, чья доля велика в выборке. Значимый контроль принадлежит директорам предприятий, которые упрочили свое положение за счет перераспределения акций от рядовых работников предприятий. Государство на начало 2006 г. присутствовало как держатель контрольного пакета на $6,84 \%$ компаний выборки. Государство как контролирующий собственник к настоящему времени практически не сократило доли своего участия в тех компаниях, где остался контрольный пакет, динамика корпоративного контроля в 2002-2005 гг. крайне незначительна.

В целом государственный контроль над предприятиями выборки наиболее распространен в случаях, когда на предприятии присутствует не только контролирующий, но и блокирующий собственник. В основном контроль государства над деятельностью уральских компаний берет свое начало с приватизации крупных и средних промышленных предприятий Урала. Несколько волн передела собственности в региональных компаниях сократили долю госсектора в уральской экономике, но на наиболее значимых для экономики Среднего и Южного Урала предприятиях закрепление позиций государства сохранилось.

Перед данным исследованием ставилась задача выявления влияния государственного участия в собственности и управлении АО на характер развития совета директоров, как внутреннего механизма корпоративного управления.

Для решения этой задачи мы разделили все предприятия, участвовавшие в опросе 2006 г., на 4 группы ${ }^{23}$ :

1. Государство есть в числе собственников, но его представители не участвуют в управлении предприятием (8 АО).

2. Государство не присутствует в собственности, но его представители участвуют в управлении предприятием (4 АО).

3. Государство участвует в собственности и в управлении предприятием через своих представителей (14 АO).

4. К этой группе отнесены компаний без оформленного участия государства в собственности и управлении (47 АО).

Среди характеристик работы совета были выделены состав и структура совета директоров, качество которого измерялось следующими переменными:

- наличие независимых директоров в составе совета;

- наличие специализированных комитетов в составе совета.

Таблица 13. Государство и работа совета директоров, 2006 г.

\begin{tabular}{|l|l|l|l|}
\hline $\begin{array}{c}\text { Участие государства / качество } \\
\text { корпоративного управления }\end{array}$ & $\begin{array}{c}\text { Независи- } \\
\text { мые } \\
\text { директора }\end{array}$ & $\begin{array}{c}\text { Комите- } \\
\text { ты в } \\
\text { составе } \\
\text { СД }\end{array}$ & $\begin{array}{c}\text { Увольнение СЕО по } \\
\text { решению СД или } \\
\text { стратегического } \\
\text { собственника }\end{array}$ \\
\hline В собственности & $50 \%$ & $87,5 \%$ & $50 \%$ \\
\hline В управлении & $25 \%$ & $75 \%$ & $25 \%$ \\
\hline В собственности и управлении & $21 \%$ & $36 \%$ & $50 \%$ \\
\hline Ни в собственности, ни в управлении & $19 \%$ & $57 \%$ & $55 \%$ \\
\hline
\end{tabular}

Для совета директоров можно сказать, что частные компании, привлекающие и не привлекающие государственных представителей к управлению, более активно используют этот механизм корпоративного управления, нежели компании с государственным участием. Участие в работе совета директоров представителей государства является показателем использования государством механизмов защиты своих интересов как собственника. Для

\footnotetext{
${ }^{23}$ Данные по этим вопросам наиболее полно представлены в опросе 2006 г. Всего предприятий, из выборки, давших значимые ответы по всем вопросам - 73 АО.
}

Выпуск \#4, 2007 구의 Электонный журнал Корпоративные Финансы, 2007 
предприятий с участием государства в собственности случаи, когда государство, являясь собственником, одновременно представлено в совете, встречаются в полтора раза чаще, чем случай с отсутствием представителя в совете (14 АО против 8 AО). И среди прочих на 4 АО есть представители государства в составе совета, при этом государства нет в списке собственников.

\section{Заключение}

Результаты, полученные в ходе исследования, можно кратко сформулировать в виде следующих вводов.

Высокая концентрация собственности в региональных компаниях - наиболее распространенный механизм мониторинга. В большинстве региональных компаний агентская проблема решается путем объединения собственности и управления при высокой концентрации собственности. Концентрированная внешняя собственность стимулирует развитие агентской природы совета. Средний размер контрольного пакета аутсайдеров (в т. ч. у государства) больше, чем у акционеров-инсайдеров: концентрация собственности выступает механизмом мониторинга работы менеджмента в случае, когда у инвестора нет дополнительных инструментов контроля (участие в СД). При инсайдерской собственности концентрация ниже, чем при внешней собственности, что говорит о том, что внешним инвесторам для сохранения контроля необходима более высокая концентрация собственности, а инсайдеры имеют дополнительные инструменты контроля. Концентрация собственности не оказывает значимого влияния на присутствие менеджмента в советах директоров. Сращивание менеджмента с советом снижает роль совета в мониторинге. В то же время доминирующие собственники используют совет для усиления своего влияния на решения компании, а при условии средней концентрации усиливается возможность влияния на совет институциональных инвесторов.

Основной тенденцией развития совета как внутреннего инструмента корпоративного управления является развитие его функций, состава и структуры. Большее число комитетов в советах, высокая сменяемость состава и председателя совета являются позитивными тенденциями в корпоративном управлении.

Нетривиальная роль государства отличает работу региональных компаний. Участие государства в собственности поддерживает институт концентрированной собственности. Масштабы государственного участия в собственности компаний остаются значительными и относительно стабильными, в ряде случаев наблюдается рост участия; в целом ослабляется контроль государства через собственность. Государство выступает гарантом прав собственности и инициатором импорта норм корпоративного управления. В отношении работы совета директоров можно отметить рост агентской природы совета в компаниях с государственным участием. Государству как акционеру необходимо поддерживать свое влияние на компанию, при этом формализация связей между компаниями и государством приводит ко все более частому использованию советов директоров для этих целей.

\section{Список литературы}

1. Авдашева С.Б., Долгопятова Т.Г., Пляйнес Х. Корпоративное управление в АО с государственным участием: российские проблемы в контексте мирового опыта. Препринт WP1/2007/01. М.: Издательский дом ГУ-ВШЭ, 2007. - 52 с.

2. Гуриев С.М., Лазарева О.В., Рачинский А.А., Цухло С.В. Корпоративное управление в российской промышленности. Серия «Научные доклады: независимый экономический анализ», № 149. М.: МОНФ, ЦЭФИР, 2003.

3. Долгопятова Т. Модели и механизмы корпоративного контроля в российской промышленности (опыт эмпирического исследования) // Вопросы экономики. 2001. № 5. C. $46-60$. 
4. Долгопятова Т. Собственность и корпоративный контроль в российских компаниях в условиях активизации интеграционных процессов // Российский журнал менеджмента. 2004. Т. 2. № 2. С. 3-26.

5. Долгопятова Т. Концентрация акционерной собственности и развитие российских компаний (эмпирическое свидетельство) // Вопросы экономики. 2007. № 1. С. 84-97.

6. Долгопятова Т.Г., Уварова О.М. Эмпирический анализ организации корпоративного контроля в российских компаниях / Препринт WP1/2007/ Серия WP1. Институциональные проблемы российской экономики. М.: Изд.: ГУ-ВШЭ, 2007 - 35 c.

7. Капелюшников Р., Демина Н. Влияние характеристик собственности на результаты экономической деятельности российских промышленных предприятий // Вопросы экономики. 2005. № 2. С. 53-68.

8. Кузнецов П.В., Муравьев А.А. Механизмы участия государства в управлении акционерными обществами государственной и смешанной форм собственности в России // Вестник СПбГУ. Сер. 8. 2002. Вып. 1 (№ 8). С. 34-57.

9. Радыгин А.Д., Энтов Р.М. Корпоративное управление и защита прав собственности: эмпирический анализ и актуальные направления реформ: Научные труды ИЭПП № 36. М.: ИЭПП, 2001.

10. Развитие спроса на правовое регулирование корпоративного управления в частном секторе. Серия «Научные доклады: независимый экономический анализ», № 148. М.: МОНФ, АНО «Проекты для будущего», 2003.

11. Розинский И.А. Механизмы получения доходов и корпоративное управление в российской экономике // Российские предприятия: корпоративное управление и рыночные сделки. М.: Изд-во ГУ-ВШЭ, 2002 - с. 168-181.

12. Структурные изменения в российской промышленности / под ред. Е.Г.Ясина. М.: Изд. дом ГУ-ВШЭ. 2004.

13. Структура и организация деятельности советов директоров российских ОАО/

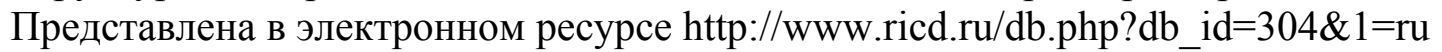

14. Яковлев А. Спрос на право в сфере корпоративного управления: эволюция стратегий экономических агентов // Вопросы экономики. 2003[б]. № 4. С. 37-50.

15. Яковлев А.А. Меры государственной поддержки в промышленности: масштабы, адресаты, эффективность [Электронный ресурс] / Яковлев А.А. - Режим доступа: http://www.opec.ru/yakovlev/

16. Яковлев А. А. Эволюция стратегий взаимодействия бизнеса и власти в российской экономике // Российский журнал менеджмента. Т. 3, № 1, 2005. С. 27-52.

17. Яковлев А.А. Данилов Ю.А. Российская корпорация на 20-летнем горизонте: структура собственности, роль государства и корпоративное финансирование. //Российский журнал менеджмента. 2007. № 1. С. 3-34.

18. Яковлев А.А. Российская корпорация и региональные власти: эволюция модели взаимоотношений // Вопросы экономики. 2007. № 1. С. 124-139.

19. Ясин Е. В складчину с государсвом. [Электронный ресурс] / Е. Ясин / Российская газета - Режим доступа http://www.rg.ru/2004/11/17/v_sklad4inu.html

20. Dolgopyatova T., Iwasaki I. Exploring Russian Corporations: Interim Report on the JapanRussia Joint Research Project on Corporate Governance and Integration Processes in the Russian Economy: IER Discussion Paper Series B N 35. Tokyo: Hitotsubashi University, Institute of Economic Research, 2006. 


\section{Приложения}

Таблица 1. Распределение предприятий по отраслям промышленности: сопоставление статистических данных и обследования предприятий, \% к числу предприятий

\begin{tabular}{|c|c|c|c|c|}
\hline & \multirow{2}{*}{$\begin{array}{l}\text { Выборка } \\
\text { промышленных } \\
\text { АО } \\
\text { (1) }\end{array}$} & \multirow{2}{*}{$\begin{array}{l}\text { Генеральная } \\
\text { выборка } \\
\text { промышленных } \\
\text { АО } \\
\text { (2) } \\
\end{array}$} & \multicolumn{2}{|c|}{$\begin{array}{l}\text { Совокупность } \\
\text { действующих } \\
\text { предприятий* }\end{array}$} \\
\hline & & & (3) & (4) \\
\hline $\begin{array}{l}\text { Топливно- } \\
\text { энергетический } \\
\text { комплекс }\end{array}$ & 3 & 2,9 & 2,8 & 3,2 \\
\hline $\begin{array}{l}\text { Металлургия } \\
\text { (черная и цветная) }\end{array}$ & 21 & 2 & 2 & 2,3 \\
\hline $\begin{array}{l}\text { Машиностроение } \\
\text { металлообработка }\end{array}$ & 23 & 32,4 & 32,1 & 36,5 \\
\hline $\begin{array}{l}\text { Химическая } \\
\text { нефтехимическая } \\
\text { промышленность }\end{array}$ & 4 & 5,7 & 5,2 & 6 \\
\hline $\begin{array}{l}\text { Лесная, } \\
\text { целлюлозно-бумажная и } \\
\text { деревообрабатывающая } \\
\text { промышленность }\end{array}$ & 3 & 15,3 & 15,4 & 17,5 \\
\hline Легкая промышленность & 4 & 6 & 9,1 & 10,4 \\
\hline $\begin{array}{l}\text { Пищевая } \\
\text { промышленность }\end{array}$ & 19 & 15 & 15,1 & 17,2 \\
\hline $\begin{array}{l}\text { Строительство, } \\
\text { промышленность } \\
\text { строительных } \\
\text { материалов }\end{array}$ & 13 & 19,1 & 6,2 & 7 \\
\hline Прочие отрасли & 10 & 1,6 & 12,1 & 0 \\
\hline
\end{tabular}

Источник: Данные на конец 2004 г. [Росстат, 2005 г. С.185-205]. Расчет в графе (2) сделан по генеральной выборке промышленных предприятий в Уральском Федеральном округе, в графе (3) сделан применительно ко всем 151 тыс. отчитавшихся в 2004 г. предприятиям промышленности, а в графе (4) - применительно к 136 тыс. предприятий, включенных в выборку отраслей промышленности. 
Таблица 2. Среднесписочная численность работников предприятий, принявших участие в обследовании

\begin{tabular}{|l|l|}
\hline $\begin{array}{l}\text { Среднесписочная } \\
\text { чел. }\end{array}$ & численностн Доля выборки, \% \\
\hline 100299 & 25,86 \\
\hline $300-599$ & 6,45 \\
\hline $600-999$ & 6,45 \\
\hline $1000-2999$ & 41,94 \\
\hline 3000 и больше & 19,35 \\
\hline ИТОГО & 100,00 \\
\hline
\end{tabular}

Таблица 3. Отраслевая структура выборки, в \% от числа ОАО выборки

\begin{tabular}{|l|l|}
\hline Отрасли & $\begin{array}{l}\text { Доля предприятий } \\
\text { выборки, \% }\end{array}$ \\
\hline Черная металлургия & 6 \\
\hline Цветная металлургия & 14 \\
\hline Химическая промышленность & 7 \\
\hline Машиностроение и металлообработка & 20 \\
\hline Строительство и производство стройматериалов & 16 \\
\hline Пищевая и легкая промышленности & 12 \\
\hline Транспорт и связь & 10 \\
\hline Торговля & 7 \\
\hline Прочие & 8 \\
\hline ИТОГО & 100 \\
\hline
\end{tabular}


Таблица 4.1. Акционерный контроль на предприятиях выборки с высокой концентрацией капитала $(50 \%+1 \text { акция })^{24}$

\begin{tabular}{|l|l|l|l|l|l|l|}
\hline Тип собственника & $\begin{array}{l}\text { На начало } \\
\text { акциониро Средний } \\
\text { вания }\end{array}$ & $\begin{array}{l}\text { Пакет } \\
\text { На 2004 г. }\end{array}$ & $\begin{array}{l}\text { Средний } \\
\text { пакет }\end{array}$ & $\begin{array}{l}\text { На } \\
\text { г. }\end{array}$ & $\begin{array}{l}\text { 2005 Средний } \\
\text { пакет }\end{array}$ \\
\hline Государство & $42,11 \%$ & $58,56 \%$ & $17,14 \%$ & $60,88 \%$ & $19,44 \%$ & $59,47 \%$ \\
\hline Работники & $13,16 \%$ & $77,00 \%$ & $5,71 \%$ & $90,00 \%$ & $5,56 \%$ & $82,50 \%$ \\
\hline Сторонние физические лица & $15,79 \%$ & $75,85 \%$ & $25,71 \%$ & $72,30 \%$ & $22,23 \%$ & $75,77 \%$ \\
\hline Генеральный директор & $2,63 \%$ & $100,00 \%$ & $8,57 \%$ & $70,46 \%$ & $11,11 \%$ & $65,35 \%$ \\
\hline Банки & $0,00 \%$ & $0,00 \%$ & $5,71 \%$ & $94,00 \%$ & $5,56 \%$ & $91,20 \%$ \\
\hline Инвестиционные фонды & $0,00 \%$ & $0,00 \%$ & $0,00 \%$ & $0,00 \%$ & $0,00 \%$ & $0,00 \%$ \\
\hline Группа компаний & $10,53 \%$ & $66,22 \%$ & $8,57 \%$ & $72,63 \%$ & $8,33 \%$ & $82,29 \%$ \\
\hline $\begin{array}{l}\text { Независимые гридические } \\
\text { лица }\end{array}$ & $5,26 \%$ & $82,07 \%$ & $14,29 \%$ & $78,79 \%$ & $11,11 \%$ & $75,57 \%$ \\
\hline Иностранные инвесторы & $0,00 \%$ & $0,00 \%$ & $5,71 \%$ & $65,50 \%$ & $5,56 \%$ & $65,50 \%$ \\
\hline Прочие & $10,53 \%$ & $86,00 \%$ & $8,57 \%$ & $71,54 \%$ & $11,11 \%$ & $79,41 \%$ \\
\hline ИТОГО & $\mathbf{1 0 0 , 0 0 \%}$ & & $\mathbf{1 0 0 , 0 0 \%}$ & & $\mathbf{1 0 0 , 0 0 \%}$ & \\
\hline
\end{tabular}

Таблица 4.2. Акционерный контроль на предприятиях выборки с высокой концентрацией капитала $(50 \%+1 \text { акция })^{25}$

\begin{tabular}{|l|l|l|l|l|}
\hline Тип собственника & $\begin{array}{l}\text { На начало Средний } \\
\text { акционирования }\end{array}$ & Пакет & 2002 г. & $\begin{array}{l}\text { Средний } \\
\text { пакет }\end{array}$ \\
\hline Государство & $34,09 \%$ & $61,48 \%$ & $18,60 \%$ & $69,38 \%$ \\
\hline Работники & $29,55 \%$ & $73,38 \%$ & $13,95 \%$ & $67,97 \%$ \\
\hline Сторонние физические лица & $15,91 \%$ & $66,37 \%$ & $18,60 \%$ & $67,92 \%$ \\
\hline Генеральный директор & $0,00 \%$ & $0,00 \%$ & $2,33 \%$ & $62,30 \%$ \\
\hline Банки & $0,00 \%$ & $0,00 \%$ & $2,33 \%$ & $85,03 \%$ \\
\hline Инвестиционные фонды & $0,00 \%$ & $0,00 \%$ & $2,33 \%$ & $50,70 \%$ \\
\hline Группа компаний & $9,09 \%$ & $84,97 \%$ & $32,56 \%$ & $79,29 \%$ \\
\hline Юридические лица & $0,00 \%$ & $0,00 \%$ & $0,00 \%$ & $0,00 \%$ \\
\hline Иностранные инвесторы & $11,36 \%$ & $70,96 \%$ & $9,30 \%$ & $56,35 \%$ \\
\hline Прочие & $34,09 \%$ & $61,48 \%$ & $18,60 \%$ & $69,38 \%$ \\
\hline ИТОГО & $\mathbf{1 0 0 , 0 0 \%}$ & & $\mathbf{1 0 0 , 0 0 \%}$ & \\
\hline
\end{tabular}

\footnotetext{
${ }^{24}$ По данным ответов 36 компании в разрезе 2006 г., 35 компаний в разрезе 2005 г. и 38 на начало акционирования.

${ }^{25}$ По данным ответов 55 (43 компании с контрольным пакетом) компаний в разрезе 2002 г. и 55 (44 компании с контрольным пакетом) на начало акционирования.

Выпуск \#4, 2007 구의 Электонный журнал Корпоративные Финансы, 2007
} 